\title{
EFFECT OF LOADING RATE ON MECHANICAL PROPERTIES OF MICRO-SIZED OAK WOOD
}

\author{
Ümit Büyüksart ${ }^{1, \uparrow}$
}

\begin{abstract}
The aim of this study was to investigate the effect of loading rate on the micro-mechanical properties of oak (Quercus petraea) wood. Bending strength, modulus of elasticity in bending, compression strength parallel to the grain and tensile strength parallel to the grain were determined using microsized test samples. Three different loading rates were used for each test. The first loading rates were determined according to related ISO standards and the second and third loading rates were determined for half and a quarter of the standard loading rates. Results showed that the loading rate significantly affected the modulus of elasticity, tensile strength and compression strength of the oak wood, while the bending strength was not affected.
\end{abstract}

Keywords: Bending strength, compression strength, modulus of elasticity, Quercus petraea, tensile strength.

\section{INTRODUCTION}

The use of micro-sized samples to determine the mechanical properties of wood is gaining in importance. However, to date, there is no standard method for employing micro-sized test samples. Sample dimensions and loading rates vary from one study to another, while micro-sized wood samples have been used for different purposes by several researchers, including to determine the mechanical properties of earlywood and latewood sections, wood strands and fibers (Jeong 2008, Jeong et al. 2009, Groom et al. 2002, Mott et al. 2002, Kretschmann et al. 2006, Hindman and Lee 2007, Deomano and Zink-Sharp 2004, Zink-Sharp and Price 2006).

Micro-sized samples can be used to determine the mechanical properties of wood when obtaining standard-sized test samples is not possible. In order to avoid damaging wood material for further use in various applications, mechanical properties can be determined by using micro-sized test samples. Moreover, test samples of structural wood material can be taken periodically and their mechanical properties determined, thus enabling changes in the mechanical properties of the wood over time to be observed. With the development of micro-sized sample testing, strength losses due to time exposure can be determined for the structural applications of the wood. This information can provide a solid base for true assessment of the necessity of wooden structure renewal.

In previous studies, different dimensions and loading rates have been used by researchers. This situation has impeded their comparison with the results of other studies (Jeong 2008). Deomano and Zink-Sharp (2004) determined the modulus of rupture (MOR) and modulus of elasticity (MOE) of southern yellow pine (Pinus spp.), sweetgum (Liquidambar styraciflua) and yellow poplar (Liriodendron tulipifera) wood flakes using micro-sized samples by applying a loading rate of 2,54

${ }^{1}$ Department of Wood Mechanics and Technology, Faculty of Forestry, Duzce University, Duzce, Turkey.

"Corresponding author: umitbuyuksari@duzce.edu.tr

Received: 02.07.2016 Accepted: 12.01.2017 
$\mathrm{mm} / \mathrm{min}$. In another study, Hindman and Lee (2007) carried out bending and tensile tests for both earlywood and latewood sections of loblolly pine (Pinus taeda) strands using a loading rate of 0,127 $\mathrm{mm} / \mathrm{min}$ for the tensile tests. Plagemann (1982) investigated the bending properties of red oak, white oak, and sweetgum flakes with the applied loading rate of $0,029 \mathrm{~mm} / \mathrm{min}$. Hunt et al. (1989) conducted testing to determine the tensile strength and tensile modulus of yellow poplar strands (Liriodendron tulipifera) at a loading rate of $1,9 \mathrm{~mm} / \mathrm{min}$, while Zink-Sharp and Price (2006) conducted compression tests with a loading speed of $0,029 \mathrm{~mm} / \mathrm{min}$.

The effect of several factors on the tensile properties of micro-sized samples has been investigated by several researchers. Price (1976) examined the effect of gauge length on tensile strength and concluded that tensile strength increased as gauge length was increased. Jeong et al. (2008) studied the effect of strand thickness and loading rates on the tensile strength and tensile modulus of southern pine (Pinus spp.) strands. The strand thickness varied from 0,381 to $3,81 \mathrm{~mm}$, and the displacement rate ranged from 0,102 to $0,406 \mathrm{~mm} / \mathrm{min}$, thus indicating that the thickness of the sample wood strands significantly affected the tensile strength of southern pine. Their results showed that the tensile strength and tensile modulus of wood strands generally increased as the thickness increased except for the 3,81 mm thick strands. In another study, Kohan et al. (2012) investigated the effect of geometry on the tensile strength and tensile modulus of elasticity of wood strands. They compared the tensile strength and modulus of elasticity of rectangular and tapered (dog-bone shaped) wood strands and concluded that the dog-bone shaped samples had $16 \%$ and $27 \%$ higher tensile strength and modulus of elasticity, respectively, than the rectangular ones, while the variation in mechanical properties was not statistically different for the two shapes.

The wood cell wall is composed of highly organized elastic cellulose fibrils encased in a matrix of amorphous viscoelastic lignin-hemicellulose, thus indicating that its elastic and viscous (timedependent) characteristics determine its mechanical behavior (Lakes 2009). It is well known that the loading rate affects the mechanical properties of solid wood (Gerhards 1977, Gerhards and Link 1986, Spencer 1979), wood-based panels (Gerhards 1977) and wood-plastic composites (Brandt and Fridley 2003). Wood loaded at a more rapid rate yields greater strength values than that loaded at slower rates. This fact has been attributed to a number of reasons which are mostly based on the theory that failure occurs when a critical strain on the timber has been reached. The failure at lower loads takes place as a consequence of the viscous flow or creep enabled by the lower rates of loading (Dinwoodie 2000). Thus, strength can be considered as an exponential function of the loading rate over several orders of magnitude (Green et al. 1999).

There is limited information about the effect of loading rate on the tensile strength and tensile modulus of wood in micro-sized samples. Information is also lacking on the effect of loading rate on the bending strength, modulus of elasticity in bending and compression strength in micro-sized samples. Jeong et al. (2008) evaluated the effects of loading rate on the tensile properties of southern pine (Pinus spp.) strands using three different loading rates $(0,102 \mathrm{~mm} / \mathrm{min} 0,254 \mathrm{~mm} / \mathrm{min}$, and 0,406 $\mathrm{mm} / \mathrm{min}$ ). Their results showed that the tensile modulus of elasticity and tensile strength from the different loading rates were not significantly different. The current study sought to evaluate the effect of loading rate on the mechanical properties of micro-sized oak (Quercus petraea) wood.

\section{MATERIALS AND METHODS}

\section{Materials}

Six oak (Quercus petraea Lieb.) trees having straight trunks were harvested from the Duzce Forest Enterprises in the northwestern part of Turkey. Table 1 presents the properties of the sample trees. Logs of $3 \mathrm{~m}$ in length were cut from each tree at a height of $0,30 \mathrm{~m}$ and 6 -cm-thick planks including the central pith were then cut from these logs. The samples were longitudinally cut into three parts to provide homogeneity, with each part used for a different loading rate. 
Table 1. Properties of the sample trees.

\begin{tabular}{|c|c|c|c|c|c|}
\hline Tree no. & $\begin{array}{l}\text { Diameter at } \\
1,30 \mathrm{~m}(\mathrm{~cm})\end{array}$ & $\underset{\text { (years) }}{\text { Age }}$ & $\underset{\text { (m) }}{\text { Altitude }}$ & Aspect & $\begin{array}{l}\text { Slope } \\
(\%)\end{array}$ \\
\hline 1 & 34 & 203 & \multirow{6}{*}{670} & \multirow{6}{*}{ East } & \multirow{6}{*}{60} \\
\hline 2 & 39 & 207 & & & \\
\hline 3 & 38 & 138 & & & \\
\hline 4 & 40 & 193 & & & \\
\hline 5 & 41 & 214 & & & \\
\hline 6 & 40 & 204 & & & \\
\hline
\end{tabular}

All specimens were conditioned in a climate chamber at a temperature of $20{ }^{\circ} \mathrm{C}$ and a relative humidity of $65 \%$ for three weeks to a target moisture content of $12 \%$ before testing.

\section{Methods}

The micro-sized flexural test samples measured approximately $50 \times 5 \times 0,8-1,3 \mathrm{~mm}$. The tests were performed with a three-point bending fixture. The micro-sized bending test sample and test setup is shown in Figure 1.

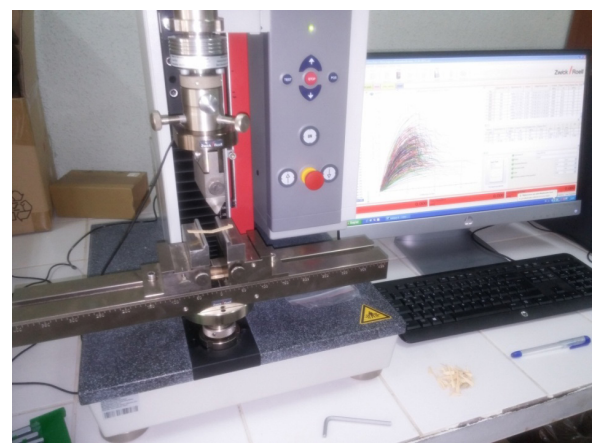

Figure 1. Micro-sized bending test sample and setup.

The micro-sized tensile test samples were approximately $50 \times 5 \times 1-1,3 \mathrm{~mm}$ and the width of the sample was reduced to $0,8 \mathrm{~mm}$ using a sanding drum. The tensile strength was calculated from the ultimate load. The micro-sized compression test specimens had dimensions of $3 \times 3 \times 5 \mathrm{~mm}$ (Figure 2). Tests on the micro-sized specimens were performed with a Zwick universal testing machine using a $100 \mathrm{~N}$ load cell for the bending and compression tests and a $1 \mathrm{kN}$ load cell for the tension tests.

Three different loading rates were used for each test. The loading rates for the first group (Group A) were determined according to ISO standards (ISO 13061-3, 2014; ISO 13061-4, 2014; ISO 13061-6, 2014; ISO 13061-17, 2014). The second (Group B) and third (Group C) loading rates were selected as half and a quarter of the standard loading rates. Table 2 shows the loading rates for all tests. 


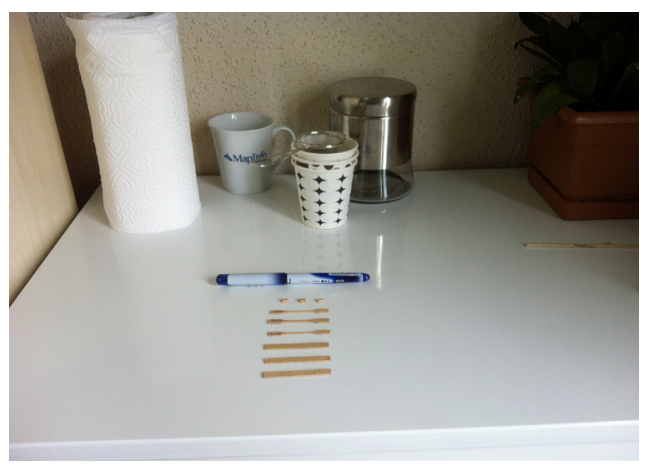

Figure 2. Micro-sized compression, tensile and bending test specimens.

Table 2. Loading rates for all test groups.

\begin{tabular}{|c|c|c|c|}
\hline \multirow{2}{*}{ Group } & \multicolumn{3}{|c|}{ Loading rates } \\
\cline { 2 - 4 } & $\begin{array}{c}\text { Compression test } \\
(\mathrm{mm} / \mathrm{min})\end{array}$ & $\begin{array}{c}\text { Tensile test } \\
(\mathrm{mm} / \mathrm{min})\end{array}$ & $\begin{array}{c}\text { Flexural test } \\
\text { MOR and MOE } \\
(\mathrm{mm} / \mathrm{min})\end{array}$ \\
\hline $\mathrm{A}$ & 0,7 & 0,3 & 1,2 \\
\hline $\mathrm{B}$ & 0,35 & 0,15 & 0,6 \\
\hline $\mathrm{C}$ & 0,175 & 0,075 & 0,3 \\
\hline
\end{tabular}

\section{Data analyses and statistical methods}

For the bending strength, modulus of elasticity in bending, tensile and compression strength, all multiple comparisons were first subjected to an analysis of variance (ANOVA) at $p<0,05$. Post-hoc comparisons were conducted using Duncan's multiple range test.

\section{RESULTS AND DISCUSSION}

The average bending strength values and Duncan test results for oak wood are shown in Table 3 . The bending strength at the standard loading rate was found to be $61 \mathrm{MPa}$ for oak wood with these values slowly decreasing when the loading rate was decreased, resulting in decreases of $3,3 \%$ and $0,2 \%$ for the half and quarter loading rates, respectively. Green et al. (1999) reported that higher strength was achieved in standard and structural-sized wood loaded at a more rapid rate than when loaded at slower rates. Thus, a load of approximately $10 \%$ higher than the load obtained in a standard static strength test was required to induce failure in $1 \mathrm{~s}$. 
Table 3. Average bending strength and modulus of elasticity in bending values and Duncan test results for oak wood.

\begin{tabular}{|c|c|c|c|c|c|c|c|}
\hline Test type & $\begin{array}{c}\text { Loading } \\
\text { rate }\end{array}$ & $\mathbf{N}$ & $\begin{array}{c}\text { Mean } \\
\mathbf{( M P a}\end{array}$ & $\begin{array}{c}\text { Std. } \\
\text { Deviation }\end{array}$ & $\begin{array}{c}\text { Std. } \\
\text { Error }\end{array}$ & $\begin{array}{c}\text { Minimum } \\
\text { value }\end{array}$ & $\begin{array}{c}\text { Maximum } \\
\text { value }\end{array}$ \\
\hline \multirow{2}{*}{ Bending } & $\mathrm{A}$ & 195 & $61,0^{\mathrm{a}}$ & 17,6 & 1,3 & 23,6 & 106,5 \\
strength & $\mathrm{B}$ & 195 & $59,0^{\mathrm{a}}$ & 18,6 & 1,3 & 22,9 & 113,2 \\
& $\mathrm{C}$ & 195 & $60,9^{\mathrm{a}}$ & 17,1 & 1,2 & 23,5 & 101,4 \\
\hline & $\mathrm{A}$ & 195 & $2531,8^{\mathrm{b}}$ & 698,8 & 50,0 & 1010,4 & 4688,8 \\
Modulus & $\mathrm{B}$ & 195 & $2180,6^{\mathrm{a}}$ & 703,7 & 50,4 & 1008,1 & 4485,6 \\
elasticity & $\mathrm{C}$ & 195 & $2189,8^{\mathrm{a}}$ & 656,2 & 47,0 & 1097,7 & 4664,8 \\
& & & & & & & \\
\hline
\end{tabular}

In the present study, however, the effect of loading rate on bending strength was not statistically significant (Table 4). The size effect, the selected loading rates and the high variability of the values could be reasons for this result. The size effect (weakest link) theory states that the strength of a highly stressed material is dependent on the size, based on the fact that a region of low strength will more likely occur in a component of large volume than in one of small volume. Thus, complete failure of the component is assumed to result from this low strength region (Weibull 1951). Both Dinwoodie (2000) and Sugiyama (1967), using higher loading rates (2 days-2 years), determined that, as a result of creep, the mechanical properties of wood were influenced by the loading rate. Lanvermann et al. (2014), however, reported that, because of the high local variability of the values, the mechanical properties were not significantly decreased. Moreover, Dinwoodie (2000) concluded that the effect of the loading rate depended on the size of the sample and that the rate was higher in structural timber than in small, clear specimens.

Table 4. Effect of loading rate on bending strength and modulus of elasticity in the bending of oak wood (ANOVA).

\begin{tabular}{|c|l|c|c|c|c|c|}
\hline Test type & & $\begin{array}{c}\text { Sum of } \\
\text { Squares }\end{array}$ & df & Mean Square & F & Sig. \\
\hline \multirow{2}{*}{$\begin{array}{c}\text { Bending } \\
\text { strength }\end{array}$} & Between Groups & 520 & 2 & 260 & \multirow{2}{*}{0,823} & \multirow{2}{*}{0,440} \\
\cline { 2 - 5 } & Within Groups & 183850 & 582 & 316 & \\
\hline \multirow{2}{*}{$\begin{array}{c}\text { Modulus } \\
\text { of } \\
\text { elasticity }\end{array}$} & Dotal & 184370 & 584 & & \multirow{2}{*}{16,576} & 0,000 \\
\cline { 2 - 6 } & Within Groups & 15625690 & 2 & 7812845 & & \\
\hline
\end{tabular}


The average modulus of elasticity values and Duncan test results for oak wood are shown in Table 3. The modulus of elasticity at the standard loading rate was found to be $2531,8 \mathrm{MPa}$ for oak wood. The modulus of elasticity values of oak wood decreased as the loading rate was decreased. The decreases in the modulus of elasticity values were $13,9 \%$ and $13,5 \%$ for the half and quarter loading rates, respectively. The effect of loading rate on modulus of elasticity was statistically significant (Table 4). As mentioned above, increased strength and stiffness values result from an increase in the loading rate (Dinwoodie 2000). Brandt and Fridley (2003) stated that the expected decrease in deflection at failure came about because the effect of the viscous flow of the material decreased with the increased loading rate.

The average tensile strength values and Duncan test results for oak wood are shown in Table 5.

Table 5. Average tensile and compression strength values and Duncan test results for oak wood.

\begin{tabular}{|c|c|c|c|c|c|c|c|}
\hline Test type & $\begin{array}{c}\text { Loading } \\
\text { rate }\end{array}$ & $\mathbf{N}$ & $\begin{array}{c}\text { Mean } \\
\mathbf{( M P a}\end{array}$ & $\begin{array}{c}\text { Std. } \\
\text { Deviation }\end{array}$ & $\begin{array}{c}\text { Std. } \\
\text { Error }\end{array}$ & $\begin{array}{c}\text { Minimum } \\
\text { value }\end{array}$ & $\begin{array}{c}\text { Maximum } \\
\text { value }\end{array}$ \\
\hline \multirow{2}{*}{$\begin{array}{c}\text { Tensile } \\
\text { strength }\end{array}$} & $\mathrm{A}$ & 190 & $96,1^{\mathrm{b}}$ & 33,3 & 2,4 & 30,4 & 187,9 \\
\cline { 2 - 8 } & $\mathrm{B}$ & 190 & $86,2^{\mathrm{a}}$ & 32,6 & 2,4 & 24,4 & 180,3 \\
\cline { 2 - 8 } & $\mathrm{C}$ & 190 & $92,5^{\mathrm{ab}}$ & 35,6 & 2,6 & 26,8 & 200,0 \\
\hline \multirow{2}{*}{$\begin{array}{c}\text { Compression } \\
\text { strength }\end{array}$} & $\mathrm{A}$ & 196 & $45,1^{\mathrm{ab}}$ & 8,9 & 0,6 & 25,6 & 68,1 \\
\cline { 2 - 8 } & $\mathrm{B}$ & 196 & $45,7^{\mathrm{b}}$ & 9,3 & 0,7 & 26,5 & 65,8 \\
\cline { 2 - 8 } & $\mathrm{C}$ & 196 & $43,4^{\mathrm{a}}$ & 8,5 & 0,6 & 27,1 & 60,2 \\
\hline
\end{tabular}

The tensile strength at the standard loading rate was found to be $96,1 \mathrm{MPa}$ for oak wood. The tensile strength values of oak wood decreased when the loading rate was decreased to half of the standard loading rate and then increased at a quarter of the standard loading rate (Table 5), thus confirming the fact that the effect of loading rate on tensile strength was statistically significant for oak wood (Table 6).

Table 6. Effect of loading rate on tensile and compression strength of oak wood (ANOVA).

\begin{tabular}{|c|c|c|c|c|c|c|}
\hline Test type & & $\begin{array}{c}\text { Sum of } \\
\text { Squares }\end{array}$ & df & $\begin{array}{c}\text { Mean } \\
\text { Square }\end{array}$ & $\mathbf{F}$ & Sig. \\
\hline \multirow{3}{*}{$\begin{array}{l}\text { Tensile } \\
\text { strength }\end{array}$} & Between Groups & 9627,0 & 2,0 & 4813,5 & \multirow{3}{*}{4,208} & \multirow{3}{*}{0,015} \\
\hline & Within Groups & 648655,8 & 567,0 & 1144,0 & & \\
\hline & Total & 658282,7 & 569,0 & & & \\
\hline \multirow{3}{*}{$\begin{array}{l}\text { Compression } \\
\text { strength }\end{array}$} & Between Groups & 566,4 & 2 & 283,2 & \multirow{3}{*}{3,57} & \multirow{3}{*}{0,029} \\
\hline & Within Groups & 46350,3 & 585 & 79,2 & & \\
\hline & Total & 46916,7 & 587 & & & \\
\hline
\end{tabular}


The decreases in tensile strength values were $10,3 \%$ and 3,7\% for oak wood for the half- and quarter-loading rates, respectively. On the other hand, Jeong et al. (2008) found that the effects of loading rate on the tensile modulus of elasticity and tensile strength of micro-sized pine wood were not significantly different, with results showing the tensile strength of micro-sized pine wood samples of $0,794 \mathrm{~mm}$ thickness to be $50,0 \mathrm{~N} / \mathrm{mm}^{2}$ at a $0,406 \mathrm{~mm} / \mathrm{min}$ loading rate $47,2 \mathrm{~N} / \mathrm{mm}^{2}$ at $0,102 \mathrm{~mm} / \mathrm{min}$ and $52,2 \mathrm{~N} / \mathrm{mm}^{2}$ at $0,254 \mathrm{~mm} / \mathrm{min}$. The differing findings between the current study and those of previous research studies might be explained by the variation in wood species, the size effect, failure modes, the form of the samples (rectangular or dog-bone shaped) and gauge lengths. Jeong (2008) concluded that comparisons with the results of previous studies were impeded by the varying dimensions and loading rates used. In a comparison of rectangular and tapered (dog-bone shaped) wood strands, Kohan et al. (2012) reported that the dog-bone shaped samples had $16 \%$ and $27 \%$ higher tensile strength and modulus of elasticity, respectively, than the rectangular samples and that there was no statistical difference in the two shapes in terms of the variation in mechanical properties. Price (1976) found that tensile strength increased with the increase in gauge length. Moreover, Jeong et al. (2008) stated that shear failures accounted for $61,3-83,9 \%$ of the failures, wedge failures for $12,9-29,0 \%$, grip and splitting failures for $10,0 \%$ or less, with no slip failures noted.

The average compression strength values and Duncan test results for oak wood are shown in Table 5. The compression strength at the standard loading rate was found to be 45,1 MPa for oak wood. The compression strength values of oak wood slightly increased then decreased when the loading rate was decreased to half and then to a quarter of the standard loading rate. The increasing and decreasing of compression strength values were $1,3 \%$ and $3,8 \%$ for the half- and quarter-loading rates, respectively. The effect of loading rate on compression strength was thus shown to be statistically significant for oak wood (Table 6). Liska (1950) also examined the effect of rapid loading and found that the maximum crushing strength increased with increases in the loading rate and determined the maximum crushing strength of Douglas fir wood to be $42,5 \mathrm{MPa}$ at a loading rate of $2,2 \mathrm{~mm} / \mathrm{min} 44,4 \mathrm{MPa}$ at $10 \mathrm{~mm} /$ min, 45,0 MPa at 19,6 mm/min 47,4 MPa at $48,4 \mathrm{~mm} / \mathrm{min}$ and $47,1 \mathrm{MPa}$ at $71,1 \mathrm{~mm} / \mathrm{min}$. He noted that a tenfold increase in the loading rate resulted in a compression strength increase of about $8 \%$. The compression strength of micro-sized samples of three different wood species was investigated in one previous study (Zink-Sharp and Price 2006). It was observed that although the compression strength of the micro-sized samples was close to that of the standard-sized samples, it was still lower than the standard (handbook) values for the three wood species. They could not explain the exact cause for this difference, but two of the possible reasons offered included the size effect and the damage created during specimen preparation, with a more significant impact being detected on the intra-ring samples than on the standard-sized ones.

\section{CONCLUSIONS}

From this study, the following conclusions can be drawn:

The effect of loading rate was statistically significant for the modulus of elasticity in bending, tensile strength and compression strength of oak wood.

The effect of loading rate was not statistically significant for the bending strength of oak wood.

The strength and modulus of elasticity values generally decreased with the decreasing loading rate. 
The highest decrease was observed for the modulus of elasticity when the loading rate was decreased to half of the standard loading rate. An increase was also observed in the compression strength when the loading rate was decreased from $0,70 \mathrm{~mm} / \mathrm{min}$ to $0,35 \mathrm{~mm} / \mathrm{min}$.

\section{ACKNOWLEDGEMENTS}

This work was supported by the Scientific and Technological Research Council of Turkey (TUBITAK Project Number: 1120815) as well as by the Düzce University Research Fund (Project Number: 2016.02.03.477).

\section{REFERENCES}

Brandt, C.W.; Fridley, K.J. 2003. Effect of loading rate on flexural properties of wood-plastic composites. Wood Fiber Sci 35(1):135-147.

Deomano, E.C.; Zink-Sharp, A. 2004. Bending properties of wood flakes of three southern species. Wood Fiber Sci 36(4):493-499.

Dinwoodie, J.M. 2000. Timber: Its Nature and Behaviour. CRC Press, USA.

Gerhards, C.C. 1977. Effect of duration and rate of loading on strength of wood and wood-based materials. Forest Service, Forest Products Laboratory, Wisconsin, USA, p. 24.

Gerhards, C.C.; Link, C.L. 1986. Effect of loading rate on bending strength of Douglas-fir 2 by 4's. Forest Prod J 36(2):63-66.

Green, D.W.; Winandy, J.E.; Kretschmann, D.E. 1999. Mechanical properties of wood. In: Wood Handbook-Wood as an engineering material. Gen. Tech. Rep. FPL-GTR-113. U.S. Department of Agriculture, Forest Service, Forest Products Laboratory: Madison, WI, p. 463.

Groom, L.; Shaler, S.; Mott, L. 2002. Mechanical properties of individual southern pine fibers. Part III. Global relationships between fiber properties and fiber location within an individual tree. Wood Fiber Sci 34(2):238-250.

Hindman, D.P.; Lee, J.N. 2007. Modeling wood strands as multi-layer composites: bending and tension loads. Wood Fiber Sci 39(4):516-526.

Hunt, M.O.; Triche, M.H.; Mccabe, G.P.; Hoover, W.L. 1989. Tensile properties of yellowpoplar veneer strands. Forest Products J 39(9):31-33.

ISO 13061-3. 2014. Physical and mechanical properties of wood -- Test methods for small clear wood specimens -- Part 3: Determination of ultimate strength in static bending. International Organization for Standardization, Geneva, Switzerland. 
ISO 13061-4. 2014. Physical and mechanical properties of wood -- Test methods for small clear wood specimens -- Part 4: Determination of modulus of elasticity in static bending. International Organization for Standardization, Geneva, Switzerland.

ISO 13061-6. 2014. Physical and mechanical properties of wood -- Test methods for small clear wood specimens -- Part 6: Determination of ultimate tensile stress parallel to grain. International Organization for Standardization, Geneva, Switzerland.

ISO/DIS 13061-17. 2014. Physical and mechanical properties of wood -- Test methods for small clear wood specimens -- Part 17: Determination of ultimate stress in compression parallel to grain. International Organization for Standardization, Geneva, Switzerland.

Jeong, G.Y. 2008. Tensile properties of loblolly pine strands using digital image correlation and stochastic finite element method. Ph.D. Thesis, Virginia Polytechnic Institute \& State University, Blacksburg, VA, USA.

Jeong, G.Y.; Hindman, D.P.; Finkenbinder, D.; Lee, J.N.; Lin, Z. 2008. Effect of loading rate and thickness on the tensile properties of wood strands. Forest Prod J 58(10):33-37.

Jeong, G.Y.; Zink-Sharp, A.; Hindman, D.P. 2009. Tensile properties of earlywood and latewood from loblolly pine (Pinus taeda) using digital image correlation. Wood Fiber Sci 41(1):51-63.

Kohan, N.; Via, B.K.; Taylor, S. 2012. A Comparison of Geometry Effect on Tensile Testing of Wood Strands. Forest Prod J 62(3):167-170.

Kretschmann, D.E.; Cramer, S.M.; Lakes, R.; Schmidt, T. 2006. Selected mesostructure properties in loblolly pine from Arkansas plantations. In: Stokke, D.D., Groom, L.H. (eds.), Characterization of the Cellulosic Cell Wall. Blackwell, Oxford, UK, pp. 149 - 170.

Lakes, R.S. 2009. Viscoelastic Materials. Cambridge University Press, New York, USA.

Lanvermann, C.; Hass, P.; Wittel, F.K.; Niemz, P. 2014. Mechanical properties of Norway spruce: intra-ring variation and generic behavior of earlywood and latewood until failure. Bioresources 9:105-119.

Liska, J.A. 1950. Effect of rapid loading on the compressive and flexural strength of wood. Forest Products Lab. Rpt. No: R1767.

Mott, L.; Groom, L.; Shaler, S. 2002. Mechanical properties of individual southern pine fibers. Part II. Comparison of earlywood and latewood fibers with respect to tree height and juvenility. Wood Fiber Sci 34(2):221-237.

Plagemann, W.L. 1982. The response of hardwood flakes and flakeboard to high temperature drying. Master's thesis, Washington State University, Pullman, WA, USA.

Price, E.W. 1976. Determining tensile properties of sweetgum veneer flakes. Forest Prod $J$ 26(10):50-53.

Spencer, R. 1979. Rate of loading effect in bending for Douglas-fir lumber. Proc. First International Conference on Wood Fracture. Forintek Canada Corp., Vancouver, BC., pp. 259-279.

Sugiyama, H. 1967. On the effect of the loading time on the strength properties of wood. A review on Japanese research. Wood Science and Technology 1(4):289-303. 
Weibull, W. 1951. A statistical distribution function of wide applicability. $J$ Appl Mech 18:293297.

Zink-Sharp, A.G.; Price, C. 2006. Compression strength parallel to the grain within growth rings of low density hardwoods. Maderas-Cienc Tecnol 8(2):117-126. 